\title{
Marta Cmiel-Bażant
}

Uniwersytet Warszawski

\section{Słoweńcy i Europa Środkowa ${ }^{1}$}

W grudniu 2006 roku w Międzynarodowym Centrum Kultury w Krakowie odbyła się konferencja zatytułowana Kraków i Lublana a mit Europy Środkowej. Jacek Purchla, redaktor tomu pokonferencyjnego, we wstępie do książki zwraca uwagę, zgadzając się z Györgym Konradem, że identyfikowanie się z mitem Europy Środkowej jest przede wszystkim kwestią światopoglądu. Dostrzega jednocześnie, iż „siła cywilizacyjna monarchii Habsburgów i jej uniformizujący charakter czytelne są w tkance Krakowa i Lublany, przesądzając o ich charakterystycznej środkowoeuropejskiej tożsamości" (Purchla, 2007, s. 8).

W czasach przynależności części ziem polskich i ziem słoweńskich do monarchii austro-węgierskiej zdarzała się wymiana kulturalna pomiędzy nimi. W okresie romantyzmu polski etnograf Emil Korytko za udział w powstaniu listopadowym został zesłany do Lublany, gdzie poznał słoweńskiego poetę

1 Artykuł powstał w ramach projektu badawczego „Idee wędrowne na słowiańskich Bałkanach (XVIII-XX w.)” sfinansowanego ze środków Narodowego Centrum Nauki, nr projektu 2014/13/B/HS2/01057.

This work was supported by a grant from National Science Centre in Poland (decision No. 2014/13/B/HS2/01057). Competing interests: no competing interests have been declared.

Publisher: Institute of Slavic Studies, Polish Academy of Sciences.

This is an Open Access article distributed under the terms of the Creative Commons Attribution 3.0 PL License (creativecommons.org/licenses/by/3.0/pl/), which permits redistribution, commercial and non-commercial, provided that the article is properly cited. ๑ The Author(s) 2018. 
romantycznego - France Prešerna. Korytko zaznajamiał go z polską literaturą. Inny przyjaciel Prešerna, wybitny językoznawca Jernej Kopitar, studiował we Lwowie. Znał dobrze polski romantyzm, zwłaszcza twórczość Mickiewicza i rozmawiał o niej z Prešernem. Kilkadziesiąt lat później inny Polak - Henryk Bogdański podróżował po południowej Europie, także po ziemiach słoweńskich. Pozostawił w swoim dzienniku ciekawe opisy poszczególnych miast, między innymi Triestu i Lublany (Bogdański, 1980).

\section{Mit Austro-Węgier}

Wielu słoweńskich intelektualistów również próbowało znaleźć odpowiedź na pytanie, czym właściwie jest Europa Środkowa, jak zakreślić jej granice i co łączy znajdujące się w jej obrębie państwa. W esejach pisarza Draga Jančara idea Europy Środkowej inspirowana jest właśnie intelektualną atmosferą monarchii austro-węgierskiej z początku XX wieku. Według filozofa Tinego Hribara złota doba austro-węgierskiej środkowoeuropejskości to okres od lat 60. XIX wieku do czasu wybuchu I wojny światowej (Hribar, 1991, s. 30).

Słoweńska badaczka Simona Škrabec (Škrabec, 2007, s. 11) stwierdza, że za powiązanie pojęcia Europy Środkowej z idyllicznym obrazem cesarstwa habsburskiego jest odpowiedzialna praca doktorska Włocha - Claudia Magrisa Il mito absburgico nella letteratura austriaca moderna (Magris, 1963). Utrwaliła się bowiem jej błędna interpretacja, wysuwająca właśnie to utożsamienie na plan pierwszy, a przesłaniająca główny cel autora, którym według Škrabec było zrekonstruowanie mitu o narodzinach cesarstwa Habsburgów. Literacki mit Austro-Węgier, tworzony przez Austriaków, opiewa jednoczącą siłę tego państwa, harmonię w różnorodności. Odrodził się na tym gruncie i wzmógł, jak zauważa badaczka, tuż po II wojnie światowej, jako ucieczka od teraźniejszości, rozdartej żelazną kurtyną. W Słowenii stał się popularny w latach 80 . XX wieku, kiedy to coraz poważniej zaczęto myśleć o odłączeniu się od Jugosławii. Magris pominął w swoim dziele pisarzy, którzy kwestionowali tenże mit. Sam odżegnywał się jednak od tak wąskiego pojmowania Europy Środkowej. Jak poświadcza literaturoznawca Lado Kralj, na sympozjum o Europie Środkowej, które odbyło się w Budapeszcie w 1989 roku, Claudio Magris stwierdził, że Europy Środkowej nie można utożsamiać $\mathrm{z}$ niemieckim historyczno-politycznym pojęciem Mitteleuropa, pod którym 
kryje się dominacja i konflikt kultury niemieckiej z pozostałymi kulturami regionu (Kralj, 2005, s. 354). Ten wątek został jednak pominięty w utopijnej wizji Europy Środkowej, opartej na micie Austro-Węgier. Słoweński historyk Božo Repe wysunął wręcz tezę poświadczającą, że w okresie od końca XIX wieku do wybuchu I wojny światowej w monarchii austro-węgierskiej uformowała się wspólna kultura czerpiąca z tradycji Wschodu i Zachodu, którą można określić jako specyficzną kulturę środkowoeuropejską (Repe, 1999, s. 311). W rzeczywistości, szczególnie w latach poprzedzających tę wojnę, nasilał się konflikt pomiędzy słoweńskim a niemieckim ruchem narodowym, dochodziło nawet do bezpośrednich starć podczas zgromadzeń czy demonstracji w miastach, w których obie grupy narodowe miały reprezentatywną liczbę przedstawicieli.

\section{Słoweńcy a Europa Środkowa u schyłku Jugosławii}

Słoweńcy na początku XX wieku, mimo braku własnego państwa - będąc częścią Austro-Węgier - byli narodem o uformowanej kulturowo samoświadomości. Przyczyniła się do tego m.in. praca u podstaw: propagowanie czytelnictwa przez Towarzystwo św. Mohora, zakładanie szkół z wykładowym językiem słoweńskim, wydawanie słoweńskich podręczników. Jak twierdzi Stefan Bratkowski, Słoweńcy w chwili przystąpienia do federacji dalece górowali cywilizacyjnie i kulturalnie nad resztą narodów Jugosławii (Bratkowski, 2002). Dystansując się wobec tej jednoznacznie afirmatywnej oceny, warto zwrócić jednak uwagę na różnice kulturowe i instytucjonalne, wynikające m.in. z uprzedniej przynależności do różnych organizmów państwowych. Słoweńcy czuli się kulturowo i politycznie marginalizowani w Socjalistycznej Federacyjnej Republice Jugosławii (w skrócie SFRJ). Różnice polityczno-społeczno-kulturowe pomiędzy Słowenią a republikami dominującymi prowadziły do dążenia Słowenii w latach 80. XX wieku do zwiększenia autonomii znacznie bardziej niż do zacieśniania integracji. Słoweńcy identyfikowali się wówczas o wiele bardziej z Europą Zachodnią. Chodziło też o konflikt interesów ekonomicznych. Słowenia, według Tonego Peršaka, w 1988 roku była już bliska przejścia w fazę społeczeństwa ponowoczesnego i postindustrialnego. SFRJ potrzebowała dużych nakładów finansowych na wsparcie rozwoju biedniejszych części państwa, dlatego przeznaczała na 
kulturę o wiele mniej funduszy, niż oczekiwali Słoweńcy posiadający mały rynek zbytu wytworów kultury, a chcący zwiększyć w tym sektorze nakłady do poziomu państw rozwiniętych. Centralistyczne działania były zatem odczuwane w Słowenii jako wstrzymywanie jej cywilizacyjnego rozwoju (Peršak, 1988, s. 800).

Politycznie, gospodarczo oraz kulturowo rozumiana i odczuwana w Jugosławii peryferyjność Słowenii, wartościowana pozytywnie, wzmagała pogłębianie różnic kulturowych w debacie publicznej. W skrajnych przypadkach dochodziło do negatywnego interpretowania pojęcia „bałkańskości” jako przeciwieństwa cywilizacji. Pojęciami „europejskość” i „bałkańskość” posługiwano się jako wykluczającymi się wzajemnie, przy czym ta pierwsza była synonimem rozwoju, druga zaś prowincjonalności.

Europa Środkowa w czasach komunistycznych funkcjonowała przede wszystkim jako utopia pozwalająca mentalnie wyzwolić się od komunistycznej ideologii. Znany i często cytowany przez Słoweńców esej Milana Kundery Zachód porwany albo tragedia Europy Środkowej z 1983 roku był apelem o polityczne zaangażowanie $\mathrm{w}$ walce $\mathrm{z}$ totalitaryzmem. W odpowiedzi na to wezwanie i na żywotność idei Europy Środkowej w 1990 roku przygotowywano zbiór esejów pod tytułem Srednja Evropa. Do współpracy zaproszono wybitnych humanistów. W tomie, opublikowanym w 1991 roku, zamieszczono również artykuły napisane przez przedstawicieli innych państw regionu. Próbowano w nim odpowiedzieć przede wszystkim na pytanie, czym jest dla Słoweńców Europa Środkowa (Vodopivec, 1991).

Według słoweńskiego filozofa Tinego Hribara granice Europy Środkowej pokrywają się z granicami monarchii austro-węgierskiej przed I wojną światową. Jak zauważa, tak pojmowana „Europa Środka” znajduje się w całości w południowej części kontynentu, choć jej polityczne i kulturowe centrum stanowiła przez długie lata (najbardziej wysunięta na północny zachód) dzisiejsza Austria (Hribar, 1991, s. 27). Słoweńscy intelektualiści do momentu powstania uniwersytetu w Lublanie w 1919 roku kształcili się głównie w Wiedniu. Wiedeń był wówczas dla Słoweńców, jak napisał Lado Kralj, aż do II wojny światowej, oknem na świat (Kralj, 2005, s. 359). Jugosławia składała się według Hribara z części środkowoeuropejskiej i bałkańskiej. O pojęciu Europy Środkowej nie możemy mówić w sensie geopolitycznym, twierdzi filozof, wątpliwe też jest jego polityczno-kulturowe znaczenie. Pozostaje zatem tylko jej duchowy wymiar (Hribar, 1991, s. 28). Duchowy ideał Europy Środkowej jako tworu transnacjonalnego Hribar stawia za wzór 
dla całego kontynentu, upatrując w nim sposobu na przełamanie opozycji Zachód - Wschód (Hribar, 1991, s. 39).

France Bučar, analizujący ideę Europy Środkowej z socjologicznego punktu widzenia, również zwraca uwagę, że narody ją zamieszkujące ukształtowały się pod wpływem idei ponadnarodowego pojmowania państwowości (Bučar, 1991, s. 55-66). Nie znały pojęcia granic, mając możliwość swobodnego przemieszczania się w jej obrębie, dlatego trudno jest dziś zakreślić krańce Europy Środkowej, jako że nie zostały ustanowione historycznie. Ta polityczna idea, zniszczona przez niemiecki nacjonalizm, powinna być według Bučara wzorcem dla współczesnej Europy, pozwalającym nadbudować wspólnotę ponad państwami narodowymi tak, aby powstała „Europa ojczyzn”, a nie nacjonalistycznych państw. Autor eseju dokonuje zatem również mityzacji przeszłości Austro-Węgier.

Pisarz Marjan Rožanc w swoim eseju podkreśla kulturową odrębność Słoweńców wobec pozostałych narodów tworzących Jugosławię, którą uznaje za twór wyłącznie polityczny. Dążenie do utworzenia państwa narodowego jest dla niego środkowoeuropejskim dziedzictwem. Kwestią Europy Środkowej w okresie tuż przed rozpadem Jugosławii zajmowali się także słoweńscy literaturoznawcy. Janko Kos podjął się analizy dynamiki rozwoju literatur, które można uznać za środkowoeuropejskie, ponieważ nie przynależą ani do europejskiego Zachodu, ani do Wschodu (są to literatury położone pomiędzy niemiecką i austriacką na Zachodzie a ukraińską i białoruską na Wschodzie, Kos włącza do tego grona literatury państw bałtyckich, chorwacką i północno-serbską literaturę Wojwodiny, a wyłącza tradycję literacką państw bałkańskich jako pozostającą pod wpływem tradycji bizantyńskiej). Wymienione literatury narodowe dzieli na dwie grupy - literatur centralnych i peryferyjnych, zaliczając literaturę słoweńską w okresie przed końcem XVII wieku do tych drugich, ponieważ nie przejawiły się w niej charakterystyczne dla kręgu europejskiego epoki literackie. Porównując rozwój gatunków literackich w rodzimej twórczości z centralnymi literaturami regionu, Kos zauważa, że słoweńscy pisarze zaczęli wykorzystywać niektóre gatunki z opóźnieniem, na przykład epos, powieść, komedię i tragedię (Kos, 1990, s. 20). Patrząc w przeszłość ziem słoweńskich z perspektywy polityki państwowej, badacz literatury i kultury uznaje je za niewątpliwie środkowoeuropejskie. Podaje kilka powodów. Między innymi fakt, że hrabiowie cylejscy, władający licznymi ziemiami w tym rejonie Europy, dążyli do regionalnego zjednoczenia. Poza tym ziemie słoweńskie Habsburgowie przyłączyli do swojego państwa jako jedne z pierwszych (Kos, 1990, s. 22). 


\section{Słowenia jako najbardziej „przejściowa” część Europy Środkowej}

Socjolog i polityk Dimitrij Rupel podkreśla wyjątkowość słoweńskiego położenia w Europie:

Przy czym podkreślam, że Europa Środkowa w całości (o czym świadczy choćby jej nazwa), a Słowenia w szczególny sposób, są w pewnym sensie miejscem przejściowym. Zatem Słowenia jest nie tylko w okresie przejściowym, lecz także w przejściowym miejscu. Słowenia jest terytorium przejścia pomiędzy kapitalizmem a socjalizmem, Alpami a Adriatykiem, między Germanami, tudzież ludami romańskimi, a Słowianami, między katolicyzmem a prawosławiem, tudzież islamem itd. Słowenia jest prawdopodobnie najbardziej „środkową”, czy też „przejściową”, częścią Europy Środkowej, czy też Europy Przejściowej (Rupel, 1991, s. 98)².

Obecnie zajmowane przez Słowenię tereny były już w czasach antycznych miejscem przecinania się szlaków komunikacyjnych. Rzymianie stworzyli tu rozbudowaną sieć dróg. Jeden z najważniejszych szlaków - bursztynowy - biegł z północy Europy przez Nizinę Panońską i Emonę (obecną Lublanę) do Akwilei. Tędy ludy barbarzyńskie docierały do Włoch. Inny trakt biegł z Akwilei na półwysep Istria, aż do Puli. Po przybyciu Słowian terytorium zajmowane obecnie przez Słowenię znajdowało się we władzy organizmów państwowych leżących na północ od niego. Długie lata spędzone przez Słoweńców w cesarstwie austriackim, przekształconym później w monarchię austro-węgierską, nadały jej architekturze, sztuce i kulturze „środkowoeuropejskiego charakteru”, szczególnie w epoce historyzmu w architekturze.

Lublana w swojej architekturze przechowuje pamięć o różnych okresach historycznych, projektach narodowych i przemianach tożsamości. Powstała na ruinach rzymskiego miasta - Emona, którego ślady i położenie zbadano w XVII wieku. Do dziś zachowały się m.in. fragmenty południowych murów rzymskich. Przed trzęsieniem ziemi w 1895 roku wizerunek miasta tworzyły przede wszystkim barokowe kościoły i pałace. Co ciekawe, barokowa Lublana powstała z inspiracji ówczesnym Rzymem, projektowali ją włoscy architekci. Zadecydowała o tym działająca w latach 1693-1725 w głównym mieście Krainy na rzecz rozwoju wiedzy i sztuki Akademia Operosorum Labacensium. W ostatnich dwóch dekadach XIX wieku zbudowano wiele gmachów instytucji

${ }^{2}$ Tłumaczenia z języka słoweńskiego na polski - jeśli nie zaznaczono inaczej - pochodzą od autorki tekstu. 
kulturalnych, politycznych czy gospodarczych inspirowanych głównie opartą na wzorach historycznych architekturą austriacką bądź czeską. W latach 20 . $\mathrm{XX}$ wieku odbudową miasta po trzęsieniu ziemi i systematyczną przebudową zajął się m.in. słoweński architekt Jože Plečnik, nawiązujący ponownie do antycznych i włoskich wzorów.

Plečnik studiował w Wiedniu, pod okiem Ottona Wagnera. Wyjazd na stypendium do Włoch sprawił jednak, że jak pisze słoweński historyk sztuki Peter Krečič (Krečič, 2007, s. 69-78), wychowanek wiedeńskiej Akademii Sztuk Pięknych odkrył w sobie śródziemnomorski temperament i zachwycił się tamtejszą architekturą. Mniej więcej w tym czasie w głowie Plečnika zrodził się projekt odbudowy rodzinnej Lublany, kilka lat wcześniej zniszczonej wskutek trzęsienia ziemi. Jak zauważa Krečič, architektowi udało się osiągnąć równowagę pomiędzy pierwiastkiem północnym, oznaczającym nowoczesność, a południowym, cechującym się przywiązaniem do tradycji. W jego projektach obudził się genius loci: Plečnik nawiązał do antycznej historii miasta, nadając mu przede wszystkim śródziemnomorski charakter, harmonijnie komponujący się ze środkowoeuropejskim wizerunkiem miasta i ożywiający je (Krečič, 2007, s. 69-78). Warto zwrócić uwagę, że projekt Plečnika miał również wymiar polityczny. Tworząc plan urbanistyczny Lublany, architekt opublikował też jego ideowy projekt, tytułując go Lublański zamek - słoweński Akropol. Wyobraził sobie rodzinne miasto jako nowe Ateny, podkreślając przez to jego rangę i sugerując ciągłość tradycji poprzez nawiązanie do antycznego pochodzenia miasta. Niewątpliwie był to czyn patriotyczny, symboliczne odzwierciedlenie w architekturze głównego miasta marzeń o własnej państwowości i podkreślenie kulturowej odrębności. Plečnik zmienił zupełnie oblicze jego centrum. Przekształcał budynki, czyniąc wyraźne aluzje do budowli antycznych - tworzył wzorowane na nich kolumnady i fasady, jednocześnie dbał o ich nowoczesną funkcjonalność. Jego architektura ma charakter eklektyczny. Plečnik wykorzystywał elementy weneckiego baroku, nawiązywał do renesansu, w niektórych budowlach widać fascynację architekturą ekspresjonistyczną oraz inne inspiracje. Właśnie przez tę umiejętność łączenia różnych elementów i tradycji architektonicznych, Plečnik, jak napisał Krečič: ,jawi się jako typowy przedstawiciel środowiska słoweńskich artystów, wyrażających w swej twórczości tradycje przestrzeni rozciągającej się między północą a południem Europy” (Krečič, 2007, s. 77-78). Po dziś dzień położenie miasta na przecięciu wpływów włoskich i austriackich centrów sztuki widoczne jest w jego architekturze. 


\section{Europa Środkowa w eseistyce Draga Jančara}

W eseistyce jednego z najbardziej obecnie znanych na świecie słoweńskich pisarzy, Draga Jančara, Słoweńcy występują jako naród środkowoeuropejski, w rozumieniu Milana Kundery, jako naród, którego tożsamość „potwierdziła się poprzez kulturę i literaturę", a istnienie jest zagrożone, niepewne (Jančar, 1999, s. 58). Pisarz utożsamia się z tym zakątkiem świata, czyniąc z niego swoją „literacką ojczyznę”, interioryzuje doświadczenie bycia Środkowoeuropejczykiem, budując na nim tożsamość podmiotu literackiego. Ubolewa nad moralnym upadkiem mieszkańców tego regionu Europy, piętnem historii, brakiem wolności. Europa Środkowa jest dla niego przede wszystkim modelem świata pełnego różnic, „ideą współistnienia kultur oraz ludzi, mieszkańców (i ich doświadczeń) tego zakątka naszego kontynentu" (Jančar, 1999, s. 235). Wyobrażonym i wyidealizowanym modelem świata jest tu Europa Środkowa w węższym rozumieniu pojęcia Mitteleuropa z początków XX stulecia. Jančar mitologizuje opisywaną przeszłość regionu, który jest dla niego duchowym centrum, zalążkiem świata przyszłości. Jego wizja Europy Środkowej jest przede wszystkim wyrazicielką poglądów etycznych, „centralną krainą ducha”. Jest ucieczką od świata polityki do świata kulturowej wolności i różnorodności. Eseje Jančara są przejawem pisarstwa postkolonialnego w naszej części Europy, apelem o dostrzeżenie jej specyfiki i dojrzałości kulturowej przez wielkie państwa Europy Zachodniej.

Europa Środkowa miała być dla Słowenii, dążącej do odseparowania się od Jugosławii, kartą wstępu do Europy, pisze Jančar. Jego zdaniem przyczyną idealizacji Europy Środkowej w czasie komunizmu była niemożność swobodnego funkcjonowania jednostek na jej obszarze ponad podziałami ideologicznymi (Jančar, 1993, s. 74). Ten konstrukt ideologiczny powstał zatem jako wyraz tęsknoty, nostalgii za starymi, wyidealizowanymi czasami harmonijnego współżycia kultur w Austro-Węgrzech na początku stulecia. Już po zerwaniu żelaznej kurtyny i dokonaniu przemian ustrojowych Jančar przyznał, że idea Europy Środkowej okazała się przestarzała i konserwatywna. Dziś patrzy na nią bardziej realistycznie, widzi jasne i ciemne strony przeszłości, nadal pozostaje jednak ona dla niego wzorcem współistnienia różnych narodów, cenniejszym niż ten propagowany przez Unię Europejską. Proponuje, aby zrezygnować z idealizacji, a przed Europą Środkową postawić lustro, w którym będzie można dostrzec jej zgodne z rzeczywistością odbicie (Jančar, 1999, s. 76-77). Jančar niweluje podział na wschodnią, gorszą i lepszą, zachodnią 
Europę, traktowaną jak ziemia obiecana. W jednym z esejów powstałych po odłączeniu się Słowenii od Jugosławii wyraża przede wszystkim żal po rozpadzie wspólnoty kulturowej, zapewniającej szerszy odbiór tekstów literackich, sztuk teatralnych i innych dzieł artystycznych, wydawanych i wystawianych we wszystkich republikach jugosłowiańskich.

\section{Bałkany a Europa Środkowa}

Pojęcie Europa Środkowa pojawiło się, według Boža Repe, w XIX wieku. Do nauk historycznych wprowadził je Friedrich Naumann w 1915 roku w książce Mitteleuropa, dotyczącej planów stworzenia Wielkich Niemiec, będącej częścią niemieckiej wojennej propagandy (Repe, 1999, s. 302). Naumann postulował stworzenie konfederacji o charakterze ponadnarodowym, szanującej różnorodność i odrębność małych narodów. Europa Środkowa w tym ujęciu obejmowała wszystkie kraje od Francji po Rosję, włącznie z państwami skandynawskimi, Rumunią i krajami bałkańskimi. Z czasem pojawiło się również pojęcie Europa Południowo-Wschodnia, łączące Mitteleuropę z Bałkanami i krajami wschodnioeuropejskimi. Jak twierdzi Repe, pojęciem tym posługują się głównie Niemcy i Austriacy, a na początku lat 90. utarło się również w użyciu dyplomacji międzynarodowej (Repe, 1999, s. 303). To Bałkany zostały według historyka Boga Grafenauera wydzielone z Europy Południowej jako Europa Południowo-Wschodnia, na potrzeby niemieckiej południowo-wschodniej polityki imperialistycznej (Grafenauer, 1991, s. 15).

Z perspektywy słoweńskiej kwestia przynależności Bałkanów do Europy Środkowej, a właściwie ich wykluczenia z tego kręgu kulturowego, miała w niedalekiej przeszłości przede wszystkim polityczne znaczenie. Božo Repe zauważa, że granica pomiędzy Europą Środkową a Bałkanami to rzecz ideologii i polityki. Granica ta na mentalnej mapie Europejczyków stanowiła według niego często południową granicę Europy. Po usamodzielnieniu się Słowenii w 1991 roku kluczowe stało się pytanie, do której z tych sfer przynależy Słowenia (Repe, 1999, s. 303). Dążąc do odłączenia się od Jugosławii, Słoweńcy utożsamiali się z zachodnią częścią Europy. W debacie publicznej, a zwłaszcza w eseistyce lat 80 . XX wieku, wielu intelektualistów udowadniało przynależność Słowenii do Europy Środkowej i w jej ramach widziało jej przyszłość. 
Jak pisze poeta, eseista i socjolog kultury Aleš Debeljak, Bałkany stały się w oczach Zachodu symboliczną granicą pomiędzy stabilnym, uporządkowanym i zdrowym społeczeństwem a obszarem chaosu, przemocy i niepewności, metaforą nieucywilizowanej, dzikiej mentalności Wschodu (Debeljak, 2004, s. 92-97). Zarówno autostereotyp Słoweńców, jak i wizerunek funkcjonujący wśród innych narodów byłej Jugosławii, stawiały ich po niebałkańskiej stronie tej mentalnej granicy. Słoweńców uważano za pracowitych, sumiennych, zdolnych, cywilizowanych, ale także uległych i podporządkowujących się. Postrzegani byli przez pryzmat stereotypu Austriaków - jako ich zdyscyplinowani i porządni podwykonawcy; powstało wiele określeń nawiązujących do tego wizerunku: wiedeńscy dorożkarze, austriaccy chłopi, kraińscy Janezi ${ }^{3}$, koniusze (hodowali bowiem konie lipicańskie dla cesarza). Ten stereotyp nasilił się pod koniec lat 80 . i na początku lat 90. XX wieku, wraz z zaostrzeniem się konfliktu między Słoweńcami a Serbami (Šabec, 2007, s. 114). Jego korzeni należy upatrywać w stereotypie oddanego, praworządnego obywatela, sumiennie pracującego, który zrodził się jeszcze za czasów austriackich (zob. Trstenjak, 1991). Słoweńcy postrzegają natomiast mieszkańców Bałkanów jako „južnjaków”, czyli południowców. Južnjak według Słownika Słoweńskiego Języka Literackiego to ktoś, kto mieszka w południowych, ciepłych krajach lub stamtąd pochodzi (Bajec, 2000). W największym korpusie języka słoweńskiego Gigafida można znaleźć niemal dwa tysiące przykładów użyć tego słowa, które bywa nacechowane pejoratywnie i wiązane z polem semantycznym pojęcia bałkańskość (Logar i in., 2012, zapytanie: južnjak). W ten sposób bywają określani niegdysiejsi obywatele Jugosławii, pochodzący z regionów położonych na południe od Słowenii. Problematykę stereotypu człowieka z południa podjęła słoweńska literatura (Kodrič, 2007, s. 215-220). W krótkim opowiadaniu Polony Glavan Niezwykła tożsamość Niny B (Glavan, 2004) główna bohaterka, spotykając młodzież z zachodniej Europy i z Bałkanów stwierdza, że mentalność Słoweńców mieści się gdzieś pośrodku, a ich tożsamość jest niedookreślona. W tym opowiadaniu jako przedstawiciele południowców występują głównie mężczyźni, stereotypowo opisywani jako nieuprzejmi, głośni, aroganccy, o ciemnej skórze. Podobny stereotyp południowca odmalowała Maja Novak: nieuprzejmy, pali jak Turek, arogancki, nie potrafi kulturalnie rozmawiać (Novak, 1996).

${ }^{3}$ W wojsku austriackim w czasie I wojny światowej służył słoweński pułk o tej nazwie: Pułk Kraińskich Janezów - prawdopodobnie tak zrodziła się ta etykieta. Zob. Šabec, 2007, s. 114. 
Współcześnie w niepodległej Słowenii obecne jest zjawisko jugonostalgii. Jugosłowiańskość znów staje się modna, głównie za sprawą pisarzy i działaczy kulturalnych, protestujących przeciwko marginalizacji przybyszów z południa. Debiutancka powieść Gorana Vojnovicia z 2008 roku, zatytułowana Čefurji raus! ${ }^{4}$, opowiadająca o życiu emigrantów z byłej Jugosławii w Lublanie, była w 2009 roku najlepiej sprzedającą się w Słowenii książką („Najbolj prodajana knjiga za odrasle je Vojnovićev roman Čefurji Raus!”, 2009). Wiele śladów kulturowej wspólnoty południowosłowiańskiej można znaleźć wciąż na poziomie kultury popularnej.

Wyimaginowana granica między Bałkanami a Europą jest dla Słoweńców źródłem tożsamościowych problemów. Z perspektywy Europy Zachodniej południową granicę „europejskości” wyznaczały Karawanki, masyw górski oddzielający Austrię od Słowenii. Dla Słoweńców zaś ta granica przebiegała na Kolpie, rzece płynącej pomiędzy Słowenią a Chorwacją. Słoweńska badaczka Ksenija Šabec pisze, że Słoweńcy w 2004 roku przekroczyli magiczny rubikon między Europą a Bałkanami. Jednak Europa, jak napisał Aleš Debeljak, nie wie, że Słowenia jest jej integralną częścią. Słoweńcy są zatem bałkańskimi Europejczykami i europejskimi Bałkańczykami.

\section{Zakończenie}

Tereny zamieszkiwane przez Słoweńców były częściami najbardziej wysuniętych na południe prowincji austro-węgierskich. Po I wojnie światowej Słowenia stała się zaś najbardziej północną z republik Jugosławii. W obu przypadkach były to ziemie peryferyjne i pograniczne. Peryferyjność można w tym przypadku rozumieć zarówno w wymiarze politycznym jako oddalenie od centrów decyzyjnych, jak też w wymiarze społecznym jako peryferyjność w sferze kultury znacznie różniącej się od języka i kultury narodowości dominujących. Topografia słoweńskiej tożsamości kulturowej jest zatem naznaczona nieuniknionymi przemieszczeniami w ramach Europy.

Europa Środkowa w esejach zamieszczonych w zbiorze Srednja Evropa jawi się jako przestrzeń wolna od moralnych przewinień jednych narodów

${ }^{4}$ Książka ukazała się w polskim tłumaczeniu pod tytułem Czefurzy raus!, przeł. Tomasz Łukaszewicz (Vojnović, 2008, 2010). 
względem innych, przestrzeń solidarności, niekwestionowanej różnorodności, ludzi spokojnych i skromnych, ale też skłonnych do walki o słuszną sprawę, dbających o społeczną i polityczną sprawiedliwość. Taką wizję odmalowują między innymi pisarz Marjan Rožanc i socjolog France Bučar. Jest to swoiste credo niewielkiego europejskiego narodu, wypowiedziane tuż przed wejściem na arenę międzynarodową w postaci niezależnego państwa, który motywuje swoje dążenie do niepodległości m.in. przynależnością do Europy Środkowej. Niemal wszystkie pojawiające się w książce odwołania do wspólnego dziedzictwa kulturowego dotyczą idei, osób czy wytworów sztuki pochodzących z krajów położonych na północ od Słowenii, rzadziej z sąsiedniej Chorwacji. Co najbardziej uderzające, nie pojawiają się żadne odniesienia do wielokulturowości Jugosławii, która w czasie, kiedy powstają omawiane eseje, jest u progu rozpadu. Utopijna wizja Europy Środkowej powstaje zatem w opozycji do jugosłowiańskiej rzeczywistości jako wyraz niezadowolenia $\mathrm{z}$ istniejących warunków państwowych i zarazem jako uzasadnienie kulturowej odrębności.

Słoweńcy angażują się, a nawet wręcz inicjują wiele środkowoeuropejskich inicjatyw propagujących wymianę kulturową, jak choćby projekt „Revija $\mathrm{v}$ reviji” („Czasopismo w czasopiśmie”) zakładający dzielenie się zawartością pomiędzy czasopismami wydawanymi głównie w krajach zaliczanych do Europy Środkowej. Bez pośrednictwa wielkich języków publikowane w nich teksty tłumaczone są z języka oryginału na język docelowy. W ramach projektu organizowane są także festiwale literackie, sympozja filozoficzne. W 1986 roku zaczęto organizować w Słowenii Środkowoeuropejski Festiwal Literacki, podczas którego wybrani pisarze z regionu otrzymują nagrodę literacką Vilenica (jest to nazwa jaskini znajdującej się na słoweńskim Krasie, pierwszej udostępnionej turystom do zwiedzania w Europie). Nagroda przyznawana jest przede wszystkim twórcom, którzy piszą w duchu środkowoeuropejskim. Powstało ponadto wiele publikacji historycznych, archeologicznych, kulturoznawczych, socjologicznych i literaturoznawczych oraz rozpraw z zakresu historii sztuki czy ekologii, w których różnego typu zjawiska rozpatrywane są w kontekście środkowoeuropejskim.

Do zadań, jakie wyznaczono Słowenii podczas jej prezydencji w Radzie Unii Europejskiej w pierwszej połowie 2008 roku, należało m.in. kontynuowanie negocjacji akcesyjnych z Chorwacją i Turcją, wspólne starania, wraz z innymi państwami regionu, o poprawę europejskiej perspektywy państw położonych na Bałkanach Zachodnich, przyspieszenie procesu wprowadzania standardów 
europejskich w Macedonii, Czarnogórze, Serbii, Bośni i Hercegowinie oraz w Albanii, poświęcenie szczególnej uwagi Kosowu i dbanie o zapewnienie długotrwałej stabilizacji w regionie Bałkanów Zachodnich. W ramach polityki sąsiedzkiej głównym zadaniem Słowenii było umocnienie współpracy z sąsiadami ze wschodu i południa.

Niniejszy artykuł nie wyczerpuje podejmowanego tematu. Zwraca jedynie uwagę na główne problemy tożsamościowe związane z położeniem współczesnej Słowenii na mentalnej mapie Europy. Bowiem, jak pisze Drago Jančar o swojej ojczyźnie w jednym z esejów: „Jest to naprawdę najbardziej skomplikowany zakątek Europy. Nawet my, którzy tu żyjemy, nie potrafimy go zrozumieć" (Jančar, 1993, s. 53).

\section{BIBLIOGRAFIA}

Bajec, A. (Red.). (2000). Slovar slovenskega knjižnega jezika [Źródło elektroniczne]. Pobrano 15 sierpnia 2017, z http://bos.zrc-sazu.si/sskj.html

Bogdański, H. (1980). Dziennik z podróży lat 1826 i 1827: Wiedeń-Bratysława-BudapesztZagrzeb-Rijeka-Triest-Lublana-Budapeszt-Przemyśl (J. Długosz \& J. Kosiński, Oprac.). Kraków: Wydawnictwo Literackie.

Bratkowski, S. (2002). Najdłuższa wojna księży. Wprost, 2002(7/1003).

Bučar, F. (1991). Srednja Evropa - mit ali stvarnost? W P. Vodopivec (Red.), Srednja Evropa (ss. 55-66). Ljubljana: Mladinska knjiga.

Debeljak, A. (2004). Evropa brez Evropejcev. Ljubljana: Sophia.

Glavan, P. (2004). Nenavadna identiteta Nine B. W P. Glavan, Gverilci. Ljubljana: Študentska založba.

Grafenauer, B. (1991). Srednja Evropa? Zakaj ne preprosto Evropa? W P. Vodopivec (Red.), Srednja Evropa (ss. 15-26). Ljubljana: Mladinska knjiga.

Hribar, T. (1991). Podoba Srednje Evrope. W P. Vodopivec (Red.), Srednja Evropa (ss. 27-40). Ljubljana: Mladinska knjiga.

Jančar, D. (1993). Terra incognita (J. Pomorska, Tłum.). Warszawa: Niezależna Oficyna Wydawnicza.

Jančar, D. (1999). Eseje (J. Pomorska, Tłum., K. Czyżewski, Oprac.). Sejny: Pogranicze.

Kodrič, M. (2007). Podoba „južnjaka” v kratki prozi Polone Glavan in Maje Novak. W I. Novak-Popov (Red.), Stereotipi v slovenskem jeziku, literaturi in kulturi (ss. 215-220). Ljubljana: Univerza v Ljubljani.

Kos, J. (1990). Slovenska literatura in Srednja Evropa. Slavistična revija, 1990(1(styczeńmarzec)), 11-26. 
Kralj, L. (2005). Srednja Evropa in slovenska literatura. Sodobnost, 2005(4), 353-368.

Krečič, P. (2007). Lublana, czy miasto także śródziemnomorskie? Doświadczenie Plečnika. W J. Purchla, Kraków i Lublana a mit Europy Środkowej (ss. 69-78). Kraków: Międzynarodowe Centrum Kultury.

Logar, N., i in. (2012). Gigafida [Źródło elektroniczne]. Pobrano 15 sierpnia 2017, z http://www .slovenscina.eu/korpusi/gigafida

Magris, C. (1963). Il mito absburgico nella letteratura austriaca moderna. Torino: Giulio Einaudi editore.

Magris, C. (1996). Mit habsburski (D. Filar, Tłum.). Przeglad Polityczny, 1996(31), 70-76.

Najbolj prodajana knjiga za odrasle je Vojnovićev roman Čefurji Raus! (2009, listopad 25). Dnevnik. Pobrano 23 kwietnia 2014, z https://www.dnevnik.si/1042318105

Novak, M. (1996). Propad Pirnatove hiše. W M. Novak, Zverjad. Ljubljana: Cankarjeva založba.

Peršak, T. (1988). Slovenci, Jugoslavija in slovenska kultura v luči ustavnih sprememb 1988. Sodobnost, 1988(6-7), 798-803.

Purchla, J. (2007). Wstęp. W J. Purchla (Red.), Kraków i Lublana a mit Europy Środkowej (ss. 7-9). Kraków: Międzynarodowe Centrum Kultury.

Repe, B. (1999). Slovenci, Balkan in Srednja Evropa. Anthropos, 31(4-6), 301-312.

Rupel, D. (1991). Srednja Evropa, prehodno obdobje. W P. Vodopivec (Red.), Srednja Evropa (ss. 95-106). Ljubljana: Mladinska knjiga.

Šabec, K. (2007). Kdo je čefur za kranjskega Janeza: stereotipi in kulturne razlike v sodobnem evropskem kontekstu. W I. Novak-Popov (Red.), Stereotipi v slovenskem jeziku, literaturi in kulturi (ss. 102-116). Ljubljana: Univerza v Ljubljani.

Škrabec, S. (2007). Krąg z ruchomym środkiem. W J. Purchla (Red.), Kraków i Lublana a mit Europy Środkowej (ss. 11-24). Kraków: Międzynarodowe Centrum Kultury.

Trstenjak, A. (1991). Misli o slovenskem človeku. Ljubljana: Založništvo slovenske knjige.

Vodopivec, P. (Red.). (1991). Srednja Evropa. Ljubljana: Mladinska knjiga.

Vojnović, G. (2010). Czefurzy raus! (T. Łukaszewicz, Tłum.). Gdańsk: Wydawnictwo Międzymorze.

Vojnović, G. (2008). Čefurji raus! Ljubljana: Beletrina.

\section{Słoweńcy i Europa Środkowa}

W latach 80. ubiegłego wieku, na kilka lat przed uzyskaniem przez Słowenię statusu niezależnego państwa, wielu intelektualistów - pisarzy, polityków, socjologów i historyków - próbowało znaleźć odpowiedź na pytanie, do jakiego kręgu kulturowego przynależy Słowenia. Większość identyfikowała się z koncepcją Europy Środkowej, odwołującej się do monarchii 
austro-węgierskiej z okresu od lat 60. XIX wieku do I wojny światowej. Była ona postrzegana jako państwo ponadnarodowe, które umożliwiało rozwój poszczególnych narodów i respektowało różnorodność kultur, co przyczyniło się do powstania kreatywnej, wielokulturowej atmosfery intelektualnej. Była to utopijna wizja, stworzona, aby zrównoważyć dominację ideologii komunistycznej w krajach bloku wschodniego.

Ideą znajdującą się u podłoża sposobu postrzegania Europy Środkowej przez przywoływanych słoweńskich humanistów była wyobrażona granica Europy jako pojęcia intelektualnego odpowiadającego Europie Zachodniej. Słoweńskie ziemie były częścią południowych prowincji Austro-Węgier, a po I wojnie światowej stały się najbardziej wysuniętą na północny zachód jugosłowiańską republiką. W obu przypadkach były peryferyjne w wymiarze kulturalnym i politycznym. W badanym okresie najbardziej popularna w Słowenii koncepcja Europy Środkowej wykluczała z jej ram państwa bałkańskie.

Słowa kluczowe: Europa Środkowa, Słowenia, monarchia austro-węgierska, granica wyobrażona, topografia tożsamości kulturowej, lata 80. XX wieku

\section{The Slovenes and Central Europe}

In the 1980s, a few years before Slovenia became an independent country, many intellectuals - including writers, politicians, sociologists and historians - were trying to answer the question about the cultural area in Europe to which Slovenia belonged. Most of them identified themselves with the concept of Central Europe, which was a reference to the AustroHungarian Monarchy in the period between the 1860s and the First World War. The Monarchy was perceived as a supranational state that allowed all nations to develop and respected the diversity of cultures, which gave rise to a creative and multicultural intellectual atmosphere. This utopian vision was created to balance the domination of the communist ideology in the Eastern Bloc countries.

The idea which underlied Slovenian considerations of Central Europe was that of an imagined border of Europe, whereby the latter is seen as an intellectual concept and identified with Western Europe. The Slovenian territories were a part of the southern provinces of AustriaHungary and then, after the First World War, they became the northwesternmost republic of Yugoslavia. In both cases they were peripheral in cultural and political terms. In the period that this paper is concerned with, the concept of Central Europe which was most popular in Slovenia excluded the Balkan countries.

Keywords: Central Europe, Slovenia, Austro-Hungarian Monarchy, imagined border, topography of cultural identity, 1980s 


\section{Notka o autorce}

Marta Cmiel-Bażant (marta_cmiel@interia.pl) - doktor w zakresie kulturoznawstwa slawistycznego na Uniwersytecie Warszawskim. Temat pracy doktorskiej: Słoweńska krytyka literacka w okresie międzywojennym (1918-1941). W Instytucie Slawistyki Zachodniej i Południowej prowadzi od 2011 roku kulturoznawcze i literaturoznawcze zajęcia w zakresie słowenistyki. Współautorka książki Polacy $w$ Słowenii. Zainteresowania naukowe: krytyka literacka, historia idei, kultura popularna, historii sztuki słoweńskiej, antropologia polityki.

Marta Cmiel-Bażant (marta_cmiel@interia.pl) - PhD in Slavic Cultural Studies at the University of Warsaw. The subject of her PhD thesis was Stoweńska krytyka literacka $w$ okresie międzywojennym (1918-1941) [Slovenian Literary Criticism in the Interwar Period (1918-1941)]. Since 2011, she has been teaching classes in the field of Literature and Culture of Slovenia at the Institute of Western and Southern Slavic Studies, University of Warsaw. Co-author of the book Polacy w Stowenii [Poles in Slovenia]. Research interests: literary criticism, history of ideas, popular culture, history of Slovenian art, political anthropology. 